\title{
Animal viruses, bacteria, and cancer: a brief commentary
}

\author{
Jimmy T. Efird ${ }^{1}{ }^{*}$, Stephen W. Davies ${ }^{2}$, Wesley T. O'Neal ${ }^{3}$ and Ethan J. Anderson ${ }^{4}$ \\ ${ }^{1}$ Department of Public Health, Brody School of Medicine, East Carolina University, Greenville, NC, USA \\ 2 Department of General Surgery, University of Virginia School of Medicine, Charlottesville, VA, USA \\ ${ }^{3}$ Department of Internal Medicine, Wake Forest University School of Medicine, Winston-Salem, NC, USA \\ ${ }^{4}$ Department of Pharmacology and Toxicology, Brody School of Medicine, East Carolina University, Greenville, NC, USA
}

\section{Edited by:}

Faith G. Davis, University of Alberta,

Canada

\section{Reviewed by:}

Li Tang, St. Jude Children's Research Hospital, USA

Amy Millikan Bell, US Army Public

Health Command, USA

\section{*Correspondence:}

Jimmy T. Efird, Department of Public Health, Brody School of Medicine,

East Carolina University, Greenville,

NC 27834, USA

e-mail:jimmy.efird@

stanfordalumni.org
Animal viruses and bacteria are ubiquitous in the environment. However, little is known about their mode of transmission and etiologic role in human cancers, especially among high-risk groups (e.g., farmers, veterinarians, poultry plant workers, pet owners, and infants). Many factors may affect the survival, transmissibility, and carcinogenicity of these agents, depending on the animal-host environment, hygiene practices, climate, travel, herd immunity, and cultural differences in food consumption and preparation. Seasonal variations in immune function also may increase host susceptibility at certain times of the year. The lack of objective measures, inconsistent study designs, and sources of epidemiologic bias (e.g., residual confounding, recall bias, and non-randomized patient selection) are some of the factors that complicate a clear understanding of this subject.

Keywords: animal viruses, bacteria, epidemiology, cancer, infection

\section{INTRODUCTION}

Humans and animals have coexisted since the beginning of time, sharing viruses, bacteria, and perhaps the etiology of cancers. Approximately $75 \%$ of viruses and $50 \%$ of bacteria known to cause disease in humans are zoonotic and can be transmitted between animals and people (1). While evolution has provided adaptive immunity against microbes and cancer, the ability to defend against infection is sometimes absent or compromised. Excluding ionizing radiation, sunlight, and tobacco, infection represents the main known cause of human cancers throughout the world. The list is long including cancers of the anogenital track (HPV), stomach (H. pylori), liver (HBV, HCV, liver flukes), bladder (schistosoma hematobium), prostate (XMRV), and other specific cancers such as adult T-cell leukemia (HTLV-1), Kaposi sarcoma (HHV-8), Merkel Cell Carcinoma (MCPyV), and Burkitt's lymphoma (EBV) $(2,3)$. The prevalence and persistence of tumor viruses varies in different parts of the world. Nearly $30 \%$ of cancers in developing and tropical countries are attributable to infectious causes compared with $10 \%$ in developed countries (4). However, the connection between viruses, bacteria, and cancer, and the role of animals, remains unclear or paradoxical in nature.

\section{VIRUSES}

An infectious etiology for cancer was first documented in animals during the early part of the nineteenth century with the diagnosis of pulmonary adenocarcinoma in sheep (later attributable to jaagsiekte sheep retrovirus) (5). Animals are the host species for many oncogenes. Among the most studied are rodent (Abl, Int1/Wnt1, Int2, Notch1, Pim1/2, Runx, Tpl2), fowl (Erb-b, Fos, Myc, Src), feline (Myc), and fish (cyc) (6). For example, reticuloendothesliosis virus readily induces cancer in chickens (avian leucosis/sarcoma). The virus has been found in eggs intended for human consumption and vaccines prepared in eggs (7). A wide variety of viruses, mirroring their human analogs, are ubiquitous among animals in nature and their habitat (e.g., fecal coliform contamination) (8-10). Common types include viruses in the polyoma, adeno, retro, and papilloma family.

Animal viruses potentially express oncoproteins in human cells even though stringent replicate restrictions exist in the latter (11). The "hit and run" hypothesis posits that certain viruses interfere with the hosts immune system to cause cancer, yet do not integrate into the victims DNA (leaving no detectable fingerprints) (12). Newborn hamsters infected with polyoma virus have been shown to develop cancers, even though the cells of this species do not support virus replication (13). Similarly, tumors induced in immunocompetent mammals with Rous sarcoma virus do not present neutralizing antibodies (14). In contrast, some animal viruses [e.g., feline leukemia virus $(\mathrm{FeLV})]$ have been observed to replicate in vitro in human cells $(15,16)$. Sera collected from $69 \%$ of 107 persons among 46 households with at least $1 \mathrm{FeLV}$ gs-a positive cat tested positive for antibodies against FeLV (15). Although it is unclear exactly how antibodies directed toward animal viruses could have oncogenic or mitogenic effects on host cells, these findings support the idea that long-lasting "biological memory" of animal virus exposure can exist within the host in the absence of direct effects on host DNA.

\section{BACTERIA}

Animal bacteria also have been implicated in cancer. The occurrence of gliomas in the brain of fowl have been noted in several reports (17-19) and these tumors have been described as having the pathognemonic encephalitic features of a pleomorphic parasite infection (e.g., hypertrophy and hyperplasia of bloodvessels; perivascular infiltration by lymphocytes, plasma cells, and monocytes; and the presence of A-D bodies) (20). Chickens spontaneously and experimentally infected with toxoplasma have been 


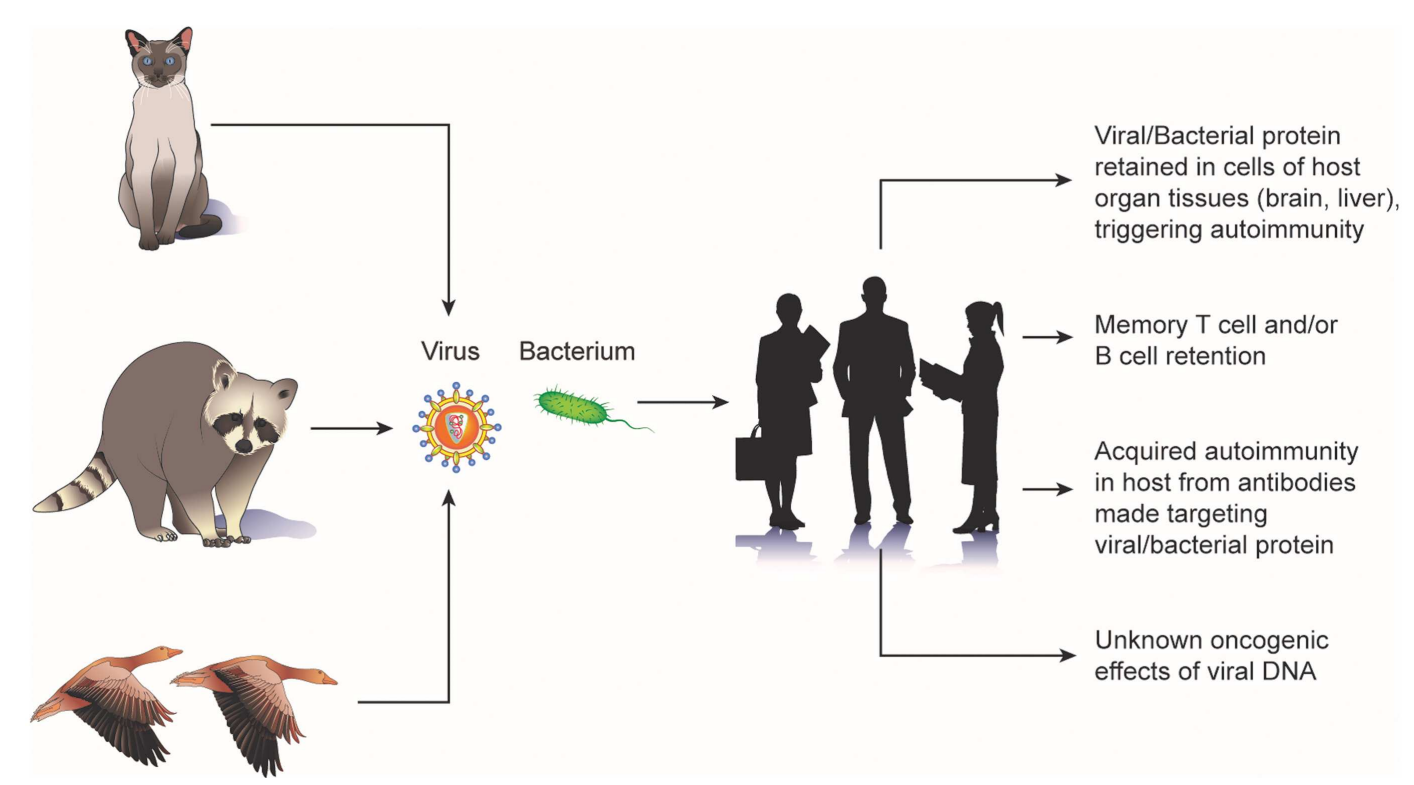

FIGURE 1 | Potential mechanisms of carcinogenic "biologic memory" retained from exposure to animal viruses and bacteria

observed to develop glioma-like tumors $(21,22)$. A study of 16 human brain tumors observed bodies indistinguishable from the $\mathrm{C}$ and D phases of the fowl parasite (23). Epizootic outbreaks of toxoplasmosis have been reported in various avian species and mammals $(22,24,25)$. Furthermore, toxoplasma antibodies have been isolated in the blood of exposed sheep farmers, flock animals, herder dogs, mice, and rats (26). Potential cellular mechanisms by which animal viruses and bacteria lead to tumorgenesis are shown in Figure 1.

\section{AGE OF EXPOSURE}

Early age at first exposure is critical for the development of many malignancies (27). Fetal or early childhood exposure to infectious agents occurs at a vulnerable time when the immune system is less developed and possibly more susceptible to tumor formation (28). The unrecognized persistence of an oncovirus or microbe in the host increases the chance for this agent to alter the cell cycle and immortalize cells $(2,29)$. Inoculation of immunologic immature neonate mice with polyoma virus results in tumor formation at multiple sites. In contrast, older mice do not develop tumors in response to polyoma virus either in the laboratory or by natural infection (13). The selective sensitivity of the fetus is further demonstrated in a study of patas monkeys wherein the administration of known carcinogenic agents in the fetal stage cause more tumors than an equivalent dose administered to juvenile monkeys $(27,30)$. Furthermore, few tumors developed when treatment was delayed until the start of the second trimester, suggesting that sensitivity was greatest during the first trimester.

\section{TRANSMISSION}

\section{EXPOSURE ROUTES AND FACTORS INFLUENCING TRANSMISSION}

Human exposure may occur in many ways - preparing and consuming animal products, washing with, and drinking well water contaminated with animal fecal coliform, animal bites/scratches, and working in occupations involving regular contact with animals, manure, soil, and/or by-products (e.g., farmers, slaughtering plant workers). Even living down-wind of a farm field fertilized with animal manure poses a potential risk. A list of major sources and exposure routes of animal-to-people transmission of viruses and bacteria is shown in Figure 2. Factors influencing the probability of disease transmission involve the proximity and temporal contact with the infectious organism, length of time that the infectious agent is present, virulence of the agent, incubation period, stability of the agent under varying environmental conditions, population density of carrier animals, husbandry practices, and control of wild rodents and insects (31). The type and maintenance of animal housing also may affect the extent to which individuals working in or around such facilities are exposure to zoonotic viruses and bacteria. Often, animal containment structures (e.g., hen houses, pig pens, cattle barns, and horse stables) may be inadequately ventilated and/or have poor waste removal systems, increasing the exposure of animals and their caretakers to dust, fecal matter, and microbes (32).

\section{MECHANICAL INTERMEDIATE HOSTS}

Infectious agents may be transmitted to humans by direct contact, fomite or mechanical vector, or intermediate hosts in which the agent multiples or develops before transmission to animal or human (i.e., metazoonoses). Examples of infectious agents requiring an incubation period prior to transmission include arboviruses, plague, and schistosomiasis (31). In the case of toxoplasmosis infection, contaminated soil and water represent a key source of infection emanating from an intermediate host $(33,34)$. Indoor/outdoor cats are a significant carrier/transmitter of Toxoplasma, shedding the organism in its feces (34). Oocysts from Toxoplasma gondii also may be transported by cockroaches and 


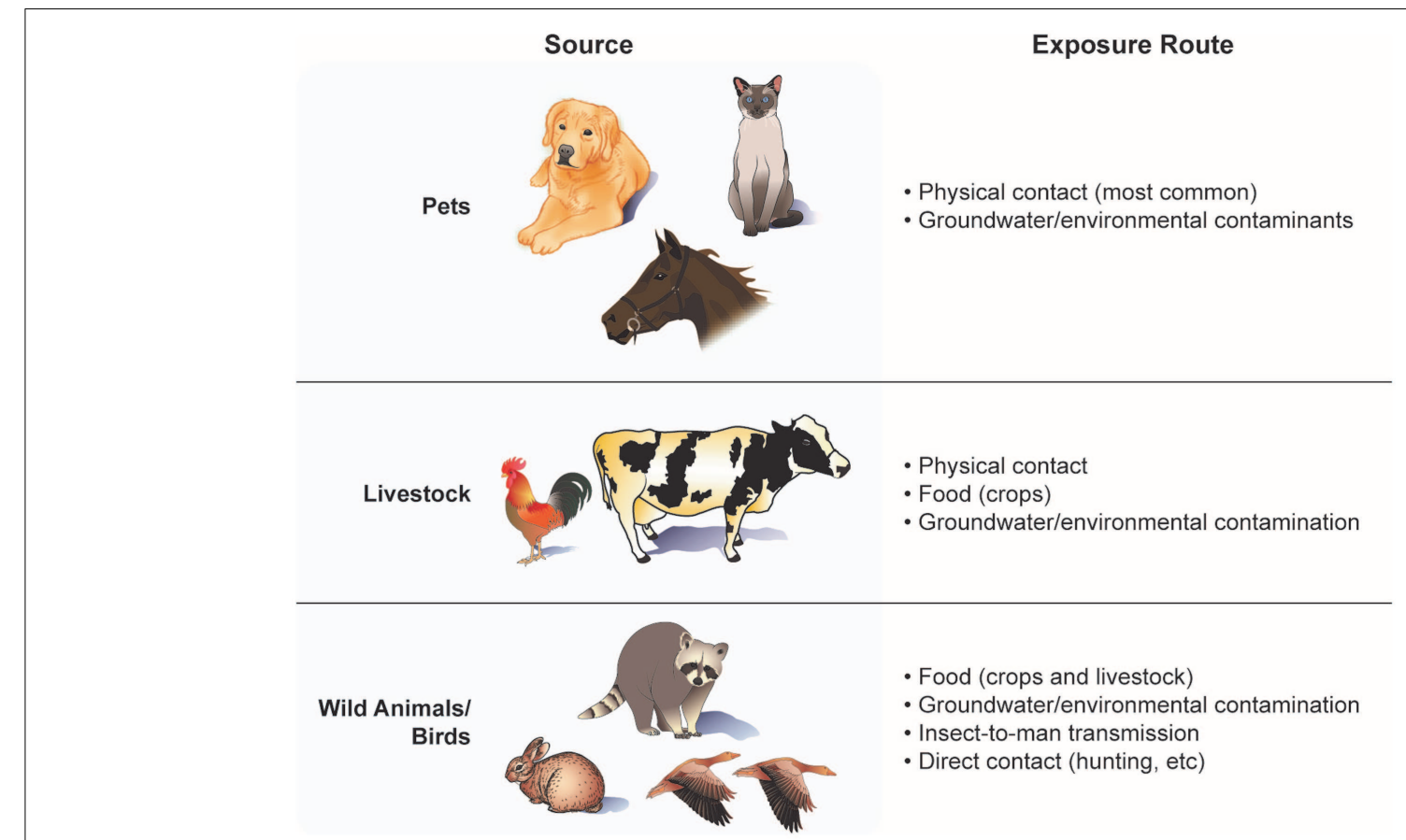

FIGURE 2 | Routes of transmission and human exposure to animal viruses and bacteria.

other bugs and deposited onto food and later consumed by animals and humans (35). In a recent study, eating raw oysters, clams, or mussels was identified as a new risk factor for $T$. gondii infection (36). The T. gondii were believed to have originated from cat feces, which survived or bypassed sewage treatment and traveled to coastal waters through river systems.

\section{FETAL INFECTION ROUTES}

Many viruses and microbes are capable of crossing the placenta. For example, the TT circovirus and several polyomaviruses (BK, JC, and SV-40) are able to cross the placenta and infect the fetus, but do not cause critical fetal abnormalities (37). In the laboratory, influenza A virus has been detected in mouse pups born of mothers exposed to influenza A virus (38). Similarly, influenza RNA has been shown to persist for at least 3 months following birth of offspring to mice infected with influenza A/WSN/33 virus during pregnancy $(39,40)$. A fetus may become infected with varicella (chickenpox) from its mother in the early weeks of pregnancy, manifesting as congenital defects particularly involving the cerebellum (41-43). Human transplancental transmission is well demonstrated by cases of fetal infection with rubella virus (44), West Nile virus (45), toxoplasmosis (46), and bovine leukemia virus (47).

\section{NON-SPECIES-SPECIFIC INFECTION}

Mice, rats, and other rodents potentially carry non-species-specific infectious diseases $(31,48,49)$. Rodents also harbor insects and arachnids such as fleas, mites, and lice that can facilitate transmission of viruses, bacteria, and parasites to and between humans $(31,49)$. Certain arthropods in the mite family are known to transmit blood-borne diseases like "Rickettsia typhi" from mice and rats to humans (49). Although mites typically are host specific, they will cross from one species to another if their choice of host is unavailable $(50,51)$. Fleas are capable of passing diseases by blood from rodents to humans including bubonic plague, typhus, bartonellosis, and tapeworm $(31,48)$. Exposure to the respiratory or urinary aerosol of rodents also poses risk for human infections (e.g., Hantavirus, Mycoplasma pulmonis, Streptococcus pneumoniae, Staphylococcus aureus, and Pasteurella multocida) $(52,53)$.

The ease with which rodents transmit infection to humans likely reflects the high degree of homology between the two species. Approximately $80 \%$ of mouse genes have a single identifiable ortholog in the human genome, while $<1 \%$ do not have any detectable human homolog (54). Occupations such as farming and agricultural work that place workers and their families in direct contact with rodents and their excretions/secretions increase the risk for infection $(53,55) . \mathrm{KIPvV}$ and WUPyV polyomaviruses have been detected in samples from children with lower respiratory tract disease, however it remains unknown if these viruses jumped species from rodents to humans (56).

\section{INDIRECT AND OTHER INTERMEDIATE MODES OF TRANSMISSION}

Domestic farm animals and cats that feed on infected rodents or share habitat with reservoir species may indirectly expose humans to rodent-borne pathogens $(31,53)$. Antibody to the rodent Hantavirus has been found in cats $(53,57-60)$. A casereferent study conducted in China found a positive association between cat ownership and Hantavirus infection (61). In the case of orthopox infection, cats have been confirmed as an active transmitter from rodents to man $(57,59,62-66)$. A prevalence of 
$4 \%$ was observed in an antibody study of orthopox infection in 200 free-roaming cats, most of which appeared to occur through bites sustained during hunting of rodents (59). Compared with other times of the year, a markedly increased incidence of feline poxvirus infection has been reported to occur during autumn, when the populations of many small mammals are at their largest and most active (67-69). Human infection from farm animals and cats/dogs typically results from direct contact with infected tissues, contaminated mucous membranes, and skin wounds; inhalation of respiratory secretions; and injuries sustained from infected animals (31).

Hantaviruses have been isolated from lung tissues of bats raising the possibility that these creatures also may pose a natural reservoir for the passing of rodent viruses to farm animals (53, 70). Bats appear to play a role as well in the infection of pigs with Menangle virus (71) and horses with Equine morbillivirus (72, 73). Notably, these mammals host a significantly greater number of zoonotic viruses per species than rodents (74). Bats also have been observed to have a greater number of interspecific "host switches" of paramyxoviruses to other mammals, compared with rodents, birds, primates, carnivores, and cetartiodactyla (74). Among humans, bats have been associated with the spread of severe acute respiratory syndrome-like corona viruses, Ebola and Marburg filoviruses, and Hendra and Nipah paramyxoviruses (74). Because of habitat encroachment and the proclivity of bats to roost in pitched roof spaces of buildings, humans are increasingly at risk for exposure to bat excreta (74).

Other intermediate modes for the transmission of infectious agents include insects and birds. Flying insects, for example, may feed on animal manure and later contaminate nearby food and water sources intended for human consumption, especially in the agricultural setting (48). Mosquitoes are known to transmit West Nile virus and Japanese B encephalitis from avian and horse hosts to humans (75-77) and conceivably may act in an analogous fashion as a carrier of oncogenic viruses between animals and humans. Lice, ticks, and other bloodsucking insects also can serve as mobile vectors to transfer neurotropic viruses (e.g., Alphavirus and Flavivirus) from reservoir host animals to other susceptible species including humans $(31,78)$. Wild ducks and migratory birds shed virus in their feces as they fly south in the fall, contaminating water on farms where chickens, turkeys, and pigs are raised (79).

\section{LOW OR NEGATIVE ANTIBODY RESPONSE}

Viruses can induce cancer in species outside their natural hosts (80-82). However, not all viruses, especially those of avian origin, easily transmit directly to humans in nature (79). Canadian wildlife personnel, who handle wild ducks when they are shedding high levels of virus, consistently have negative viral and serologic assays (83). Volunteers inoculated with high doses of avian subtypes $\mathrm{H} 4 \mathrm{~N} 8, \mathrm{H} 6 \mathrm{~N} 1$, and $\mathrm{H} 10 \mathrm{~N} 7$ failed to produce a detectable antibody response, even though $\sim 25 \%$ shed virus and had mild clinical symptoms (83). Only 2 of 27 persons in a sample of chicken farm laborers and residents regularly in contact with infected chickens and wildfowl tested positive for antibodies to Rous sarcoma virus-Bryan (RSV-B) (84). On the other hand, pigs have receptors for both avian and human viral strains and likely serve as a "mixing vessel" for genetic reassortment and subsequent introduction of genes into humans $(85,86)$.

\section{DIRECT HUMAN TRANSMISSION}

Avian viruses can directly infect humans without passing through pigs as evidenced by the recent outbreaks of influenza A strains H5N1 $(87,88)$ and H9N2 (89) in Asia, and H7N7 (90) in Netherlands $(78,91)$. The history of human infection closely parallels the domestication of the duck, which introduced respiratory-type influenza A viruses into the "farmyard (91)." H5 subtype infection initially was detected in human sera from rural China, a region known for poultry farming $(87,92)$. Approximately $30 \%$ of poultry workers sampled around the time of the 1999 H9N2 flu outbreak in Hong Kong were found to be seropositive for antibodies to the virus (89). H9N2 viruses are prevalent in domestic poultry such as chickens, ducks, geese, quail, and pigeons throughout Asia (89). In Netherlands outbreak, investigators reported a high infection rate of H7N7 among people directly involved in handling infected poultry and noted evidence for person-to-person transmission (90).

\section{ANIMAL INFECTION}

Influenza viruses have been found to occur throughout the mammalian kingdom in nature $(92,93)$ and are capable of infecting (either naturally or experimentally) animals commonly found on farms including cattle, sheep, goats, horses, mice, and cats (53, 93-95). In Vietnam, civets (a cat-like species) have tested positive for $\mathrm{H} 5 \mathrm{~N} 1$ virus (96). Inoculation with various Influenza A strains (e.g., H5N1/97, H9N2, H5N3, A/tern/So, Africa/61, and A/turkey/England/63) can cause infection of mice (93, 97-100) and cross the blood-brain barrier (97-99, 101). The naturally occurring equine H7N7 influenza virus is highly pathogenic in laboratory mice, requiring no adaptation $(99,102)$.

\section{SPECIES JUMPING}

The transmission route for over $200(\sim 14 \%)$ human pathogens remains unknown and zoonotic transfer or species jumping cannot be ruled out as a potential source of infection (1). Among known routes, infected feces and urine remain one of the most prominent modes of transmission whether by primary or secondary sources. Animals that are not susceptible to infection may still spread disease to other animals and humans if they become contaminated and share water or food sources (103). However, for domestic poultry, secondary transmission often is associated with human involvement in the agriculture setting through personnel and/or animal movement, food delivery, and the use of fomites (103). Because poultry often do not display clinical signs of infection they may not be quarantined from other animals or their human caretakers (103). Furthermore, the increasing global demand for poultry and meat products coupled with improvements in transportation, have propagated closer contact between humans and farm animals (104).

\section{EPIDEMIOLOGY}

\section{LACK OF SPECIFIC CANCER RISK ACROSS STUDIES}

Epiemiologic evidence in support of an animal-transmitted, viral or bacterial etiology for human cancers is limited and often inconsistent with respect to specific cancer risk. For example, exposure 
to farm animals or manure has been associated in some studies with childhood $(105,106)$ but not adult brain tumors $(107,108)$. A prospective cohort of 20,132 poultry, slaughterhouse workers (a group with frequent exposure to avian leucosis/sarcoma, reticuloendothesliosis, and Marek's disease viruses) were observed to have a statistically significant excess of several cancers including lung [standardized mortality ratio $(\mathrm{SMR})=1.6,95 \% \mathrm{CI}=1.3-$ 1.7], cervix $(\mathrm{SMR}=2.2,95 \% \mathrm{CI}=1.3-3.5)$, penis $(\mathrm{SMR}=8.6$, $95 \% \mathrm{CI}=1.0-31.1)$, brain/nervous system $(\mathrm{SMR}=1.7,95 \%$ $\mathrm{CI}=1.1-2.4)$, lymphoid leukemia $(\mathrm{SMR}=2.2,95 \% \mathrm{CI}=1.1-$ $4.1)$, and monocytic leukemia $(\mathrm{SMR}=9.2,95 \% \mathrm{CI}=1.1-33.4)$ (7). Results of the Agricultural Health Study, a prospective cohort study of 49,884 male farmers, observed a statistically significant relative risk $(R R)$ for non-Hodgkin lymphoma $(R R=1.6,95 \%$ $\mathrm{CI}=1.0-2.4$ ) among farmers who raised poultry (109). However, in contrast to the above study of poultry, slaughterhouse workers, the RR among farmers who raised poultry was not significantly increased for either lung cancer or leukemia. Performing veterinary services also was associated with a statistically significant excess of Hodgkin lymphoma $(\mathrm{RR}=12.2,95 \% \mathrm{CI}=1.6-96.3)$ in the Agricultural Health Study. However, an increased risk for lymphoma among veterinarians has not been observed in other studies (110, 111).

\section{VIRAL EXPOSURE}

In a medical record-based study of 83 cases and 166 referents individually matched on date of birth, sex, and hospital of birth, children of mothers who had documented evidence of a clinically diagnosed viral infection during pregnancy had an 11-fold odds ratio (OR) [confidence interval $(\mathrm{CI})=1.1-503.2$ ] for childhood neoplasm of the brain compared with unexposed mothers (112). However, none of the noted viral infections (mumps, varicella, herpes zoster, and rubella) were related to animal exposure. Similarly, a 2.4-fold OR ( $\mathrm{CI}=1.5-4.0,25$ cases) for childhood brain tumors (CBT) was observed in a nested (within Swedish birth-cohorts 1973-1989) case-referent (545 cases, 2798 referents) study of children born to mothers who reported a wide variety of neonatal viral and bacterial infections during the pregnancy of the index child (113). Significantly increased risk estimates were specifically observed for CBT subtypes "low-grade astrocytoma" $(\mathrm{OR}=2.7$, $\mathrm{CI}=1.2-5.8)$ and "high-grade astrocytoma" $(\mathrm{OR}=5.0, \mathrm{CI}=1.0$ 24.8). Neonatal urinary tract infections were associated with a 7.5-fold OR ( $\mathrm{CI}=1.3-44.9)$ for low-grade astrocytoma. This is in contrast to other case-referent studies examining vaginal and genitourinary infections during pregnancy, which did not observe a statistically significant increased OR for CBT $(106,112,114)$.

\section{BACTERIAL EXPOSURE}

Cancer also has been linked with exposure to animal bacteria. In an ecologic, medical geographic study, a statistically significant 1.8-fold increase in brain cancer risk was observed for countries with increasing prevalence (4-67\%) of T. gondii infection (115). In contrast, a case-referent study of brain cancer conducted in Australia observed no difference between participants with glioma $(n=117)$ and referents $(n=415)$ in the prevalence of antibody test-positivity (35\% test-positive in glioma versus 33\% in referents; age-, sex-, and center-adjusted OR $=1.00,95 \% \mathrm{CI}$ : $0.64-1.56$ )
(33). While it is difficult to compare the results of the above two studies given their different study designs, ecologic studies generally are considered to provide the weakest form of epidemiologic evidence (116). For example, the ecologic link between brain cancer and T. gondii infection is difficult to interpret given the lack of patient-level information on histologic subtype and pathologic grade. Similarly, ecologic findings of increased cancer risk among dairy farmers must be carefully weighed against the absence of antibodies to bovine leukemia virus in these populations (117).

\section{RANDOM CANCER SUSCEPTIBILITY}

While few epidemiologic studies alone provide convincing evidence of an animal microbial basis for cancer, the data nevertheless are suggestive of a possible effect when examined as a whole. Perhaps the excess risk observed for some cancers, but not necessarily the same cancers across studies, may reflect a random cancer susceptibility to infection and inflammation rather than a specific microbe-cancer relationship. By analogy, animal viruses and bacteria may represent a chambermaid's master key, capable of opening all hotel doors, but only if left unlocked by the guests.

\section{EXPLANATION OF INCONSISTENT FINDINGS}

Residual confounding or the lack of adjustment for factors such as population mixing, seasonality, climate, pesticides, medications, diet, and genetics may explain some of the conflicting and inconsistent results observed in the literature. Additionally, statistical results often are not appropriately adjusted for multiple comparisons and post hoc subset analyses, as was the case in a study reporting a statistically significant association between $T$. gondii infection and meningioma risk (33). Gene-environment interaction and the interplay between genes also are important puzzle pieces frequently missing from epidemiology studies of complex diseases such as cancer.

In the case of a "Hit and Run" virus, where the exposure theoretically occurred as an isolated event many years in the past, recall bias may have hindered the ability to establish causality or a temporal connection between a viral or bacterial exposure and cancer. A lack of study power, imprecision of point estimates, misclassification error, reverse causality, or selection bias represent other factors that may explain the inconsistencies observed across some studies and should be carefully considered with evaluating results $(109,112)$. Furthermore, the use of potentially carcinogenic disinfectant agents or cleaning compounds and must be taken into account as related etiologic exposures that might partially or fully explain a positive association between animal related microbial exposures and cancer.

\section{CONCLUSION}

While the general population is commonly exposed to animal viruses and bacteria, many of which are known to cause cancer in animals, the etiologic role of these exposures in human cancer remains speculative. For example, animal oncoviruses generally are species specific and do not infect or replicate easily in humans. Nevertheless, animal viruses conceivably may cause cancer in humans analogous to human and simian polyomaviruses causing tumors in non-permissive rodents. Epidemiologic studies to date have provided little evidence that animal viruses and bacteria cause 
human cancer. Future studies will need to address the complex nature of cancer taking into account multiple interacting risk factors, and perhaps a non-stationary stochastic risk that contradicts conventional research design. The latter may be especially true given the waxing and waning behavior of viruses and bacteria. The same infectious agent may present and react differently depending on a host of factors including geography, seasonal variation and climate, population density, and herd immunity. Travel, hygiene, and cultural variation in food consumption and preparation among individuals further complicate the epidemiologic study in this field.

\section{AUTHOR CONTRIBUTIONS}

Jimmy T. Efird: conception of manuscript, drafting of manuscript, critical revision of manuscript, and final approval of manuscript. Stephen W. Davies: critical revision of manuscript and final approval of manuscript. Wesley T. O'Neal: critical revision of manuscript and final approval of manuscript. Ethan J. Anderson, critical revision of manuscript and final approval of manuscript.

\section{ACKNOWLEDGMENTS}

Katherine T. Jones offered valuable comments during the writing of this manuscript and her contributions are greatly appreciated. This work was supported in part by NIH grant 2 G12 RR003061-2.

\section{REFERENCES}

1. Taylor LH, Latham SM, Woolhouse ME. Risk factors for human disease emergence. Philos Trans R Soc Lond B Biol Sci (2001) 356(1411):983-9. doi:10.1098/rstb.2001.0888

2. Parsonnet J. Introduction. In: Parsonnet J, editor. Microbes and MalignancyInfection as a Cause of Human Cancers. New York: Oxford University Press (1999). p. 3-15.

3. Feng M, Zhao J, Petek H. Atomlike, hollow-core-bound molecular orbitals of C60. Science (2008) 320(5874):359-62. doi:10.1126/science.1155866

4. Parkin DM. The global health burden of infection-associated cancers in the year 2002. Int J Cancer (2006) 118(12):3030-44. doi:10.1002/ijc.21731

5. Tustin R. Ovine jaagsiekte. J S Afr Vet Med Assoc (1969) 40:3-23.

6. Weiss R. Viruses and cancer. In: Nesse R, editor. Evolution and Medicine: How New Applications Advance Research and Practice, The Biomedical and Life Sciences Collection. London: Henry Stewart Talks Ltd (2007).

7. Johnson ES, Ndetan H, Lo KM. Cancer mortality in poultry slaughtering/processing plant workers belonging to a union pension fund. Environ Res (2010) 110(6):588-94. doi:10.1016/j.envres.2010.05.010

8. Hundesa A, Maluquer de Motes C, Bofill-Mas S, Albinana-Gimenez N, Girones R. Identification of human and animal adenoviruses and polyomaviruses for determination of sources of fecal contamination in the environment. Appl Environ Microbiol (2006) 72(12):7886-93. doi:10.1128/AEM.01090-06

9. Lancaster WD, Olson C. Animal papillomaviruses. Microbiol Rev (1982) 46(2):191-207.

10. Voisset C, Weiss RA, Griffiths DJ. Human RNA “rumor” viruses: the search for novel human retroviruses in chronic disease. Microbiol Mol Biol Rev (2008) 72(1):157-96. doi:10.1128/MMBR.00033-07

11. zur Hausen H. Proliferation-inducing viruses in non-permissive systems as possible causes of human cancers. Lancet (2001) 357(9253):381-4. doi:10. 1016/S0140-6736(00)03652-7

12. Nevels M, Täuber B, Spruss T, Wolf H, Dobner T. "Hit-and-run” transformation by adenovirus oncogenes. J Virol (2001) 75(7):3089-94. doi:10.1128/JVI. 75.7.3089-3094.2001

13. Sanders FK. Experimental carcinogenesis: induction of multiple tumors by viruses. Cancer (1977) 40(4 Suppl):1841-4. doi:10.1002/1097-0142(197710) 40:4+<1841::AID-CNCR2820400811>3.0.CO;2-N

14. Vogt PK. Avian tumor viruses. Adv Virus Res (1965) 11:293-385. doi:10.1016/ S0065-3527(08)60549-7
15. Caldwell GG, Baumgartener L, Carter C, Cotter S, Currier R, Essex M, et al. Seroepidemiologic testing in man for evidence of antibodies to feline leukemia virus and bovine leukemia virus. Bibl Haematol (1975) 43:238-41.

16. Sarma PS, Huebner RJ, Basker JF, Vernon L, Gilden RV. Feline leukemia and sarcoma viruses: susceptibility of human cells to infection. Science (1970) 168(3935):1098-100. doi:10.1126/science.168.3935.1098

17. Jackson C. The incidence and pathology of tumours of domesticated animals in South Africa - chapter IX: short notes on glioma: and on tumours of melanin pigmented cells, of muscle, of the adrenal, and of the precursors of the blood cells. Onderstepoort J Vet Sci Anim Ind (1936) 6:323-44.

18. Jungherr E, Wolf A. Gliomas in animals: a report of two astrocytomas in the common fowl. Am J Cancer. (1939) 37:493-509.

19. Belmonte V. Über ein gliom beim haushuhn. Virch Arch (1935) 294:329-33.

20. Jackson C. Relationship of glioma to encephalitis in the domestic fowl, and an associated parasitic agent. Nature (1948) 161(4090):441. doi:10.1038/161441a0

21. Erichsen S, Harboe A. Toxoplasmosis in chickens. II. So-called gliomas observed in chickens infected with toxoplasms. Acta Pathol Microbiol Scand (1953) 33(4):381-6. doi:10.1111/j.1699-0463.1953.tb01533.x

22. Schuman LM, Choi NW, Gullen WH. Relationship of central nervous system neoplasms to Toxoplasma gondii infection. Am J Public Health Nations Health (1967) 57(5):848-56. doi:10.2105/AJPH.57.5.848

23. Krynauw RA, Jackson C. Presence of a parasitic agent in various intracranial tumours of man. Nature (1948) 162(4108):147. doi:10.1038/162147a0

24. Erichsen S, Harboe A. Toxoplasmosis in chickens. I. An epidemic outbreak of toxoplasmosis in a chicken flock in South-Eastern Norway. Acta Pathol Microbiol Scand (1953) 33(1):56-71. doi:10.1111/j.1699-0463.1953.tb04799.x

25. Ratcliffe HL, Worth CB. Toxoplasmosis of captive wild birds and mammals. Am J Pathol (1951) 27(4):655-67.

26. Bartko J. [Toxoplasmosis of sheep in the lowland region of Western Slovakia]. Vet Med (Praha) (1979) 24(5):285-94.

27. Anderson LM, Diwan BA, Fear NT, Roman E. Critical windows of exposure for children's health: cancer in human epidemiological studies and neoplasms in experimental animal models. Environ Health Perspect (2000) 108(Suppl 3):573-94. doi:10.1289/ehp.00108s3573

28. Rice JM, Ward JM. Age dependence of susceptibility to carcinogenesis in the nervous system. Ann N Y Acad Sci (1982) 381:274-89. doi:10.1111/j.1749-6632. 1982.tb50392.x

29. Relman D. Chronic host-parasite interactions. In: Parsonnet J, editor. Microbes and Malignancy: Infection as a Cause of Human Cancers. New York: Oxford Press (1999). p. 19-34.

30. Rice JM, Rehm S, Donovan PJ, Perantoni AO. Comparative transplacental carcinogenesis by directly acting and metabolism-dependent alkylating agents in rodents and nonhuman primates. IARC Sci Publ (1989) 96:17-34.

31. Martin B. Zoonotic Diseases: Institutional Animal Care and Use Committee. Available from: http://research.ucsb.edu/connect/pro/disease.html

32. Clark S, Rylander R, Larsson L. Airborne bacteria, endotoxin and fungi in dust in poultry and swine confinement buildings. Am Ind Hyg Assoc J (1983) 44(7):537-41. doi:10.1080/15298668391405265

33. Ryan P, Hurley SF, Johnson AM, Salzberg M, Lee MW, North JB, et al. Tumours of the brain and presence of antibodies to Toxoplasma gondii. Int J Epidemiol (1993) 22(3):412-9. doi:10.1093/ije/22.3.412

34. Centers for Disease Control and Prevention. CDC Factsheet: Toxoplasma Infection. Division of Parasitic Diseases. Centers for Disease Control and Prevention (2004). Available from: www.cdc.gov/ncidod/dpd/parasites/toxoplasmosis/ 2004_pdf_toxoplasmosis.pdf

35. Hokelel M, Safdar A. Toxoplasmosis. Available from: http://www.emedicine. $\mathrm{com} / \mathrm{med} /$ topic2294.htm

36. Jones JL, Dargelas V, Roberts J, Press C, Remington JS, Montoya JG. Risk factors for Toxoplasma gondii infection in the United States. Clin Infect Dis (2009) 49(6):878-84. doi:10.1086/605433

37. Shiramizu B, Yu Q, Hu N, Yanagihara R, Nerurkar VR. Investigation of TT virus in the etiology of pediatric acute lymphoblastic leukemia. Pediatr Hematol Oncol (2002) 19(8):543-51. doi:10.1080/08880010290097396

38. Siem RA, Ly H, Imagawa DT, Adams JM. Influenza virus infections in pregnant mice. J Neuropathol Exp Neurol (1960) 19:125-9. doi:10.1097/00005072196001000-00013

39. Aronsson F, Lannebo C, Paucar M, Brask J, Kristensson K, Karlsson H. Persistence of viral RNA in the brain of offspring to mice infected with 
influenza A/WSN/33 virus during pregnancy. J Neurovirol (2002) 8(4):353-7. doi:10.1080/13550280290100480

40. Baldwin RT, Preston-Martin S. Epidemiology of brain tumors in childhood - a review. Toxicol Appl Pharmacol (2004) 199(2):118-31. doi:10.1016/j.taap.2003. 12.029

41. Laforet EG, Lynch CL Jr. Multiple congenital defects following maternal varicella; report of a case. N Engl J Med (1947) 236(15):534-7. doi:10.1056/ NEJM194704102361504

42. Rinvik R. Congenital varicella encephalomyelitis in surviving newborn. Am J Dis Child (1969) 117(2):231-5.

43. Juel-Jensen BE, MacCallum F. Herpes Simplex Varicella and Zoster: Clinical Manifestations and Treatment. Philadephia: Lippincott (1972).

44. Lee JY, Bowden DS. Rubella virus replication and links to teratogenicity. Clin Microbiol Rev (2000) 13(4):571-87. doi:10.1128/CMR.13.4.571-587.2000

45. Centers for Disease Control and Prevention (CDC). Laboratory-acquired West Nile virus infections - United States, 2002. MMWR Morb Mortal Wkly Rep (2002) 51(50):1133-5. Available from: http://www.cdc.gov/mmwr/preview/ mmwrhtml/mm5150a2.htm

46. Lopez A, Dietz VJ, Wilson M, Navin TR, Jones JL. Preventing congenital toxoplasmosis. MMWR Recomm Rep. (2000) 49(RR-2):59-68. Available from: $\mathrm{http}: / /$ www.cdc.gov/mmwr/preview/mmwrhtml/rr4902a5.htm

47. Van der Maaten MJ, Miller JM, Schmerr MJ. In utero transmission of bovine leukemia virus. Am J Vet Res (1981) 42(6):1052-4.

48. Williams BH. Zoonoses of small mamals. Clinician's Brief (2013). 53-6.

49. McArthur J. Diseases of rats. Rat and Mouse Gazette 1999. (1999). Available from: http://hometown.aol.com/rattlvrr/diseasepage.htm

50. Ogg B. Mites Medically Important to Humans. Educational Resource Guide \#27: University of Nebraska Cooperative Extension in Lancaster County (2001). Available from: http://lancaster.unl.edu/enviro/pest/bug.htm

51. McArthur J. What's bugging your rats and mice? Rat and Mouse Gazette. (1999). Available from: http://hometown.aol.com/rattlvrr/buggingl.htm

52. Simmons JH, Riley LK. Hantaviruses: an overview. Comp Med (2002) 52(2):97-110.

53. Williams E, Barker I. Infectious Diseases of Wild Mammals. Ames, IA: Iowa State University Press (2001).

54. Waterston RH, Lindblad-Toh K, Birney E, Rogers J, Abril JF, Agarwal P, et al. Initial sequencing and comparative analysis of the mouse genome. Nature (2002) 420(6915):520-62. doi:10.1038/nature01262

55. Ellis BA, Mills JN, Childs JE. Rodent-borne hemorrhagic fever viruses of importance to agricultural workers. J Agromed (1996) 2:7-44. doi:10.1300/ J096v02n04_03

56. Foulongne V, Brieu N, Jeziorski E, Chatain A, Rodiere M, Segondy M. KI and WU polyomaviruses in children, France. Emerg Infect Dis (2008) 14(3):523-5. doi:10.3201/eid1403.071206

57. Bennett M, Lloyd G, Jones N, Brown A, Trees AJ, McCracken C, et al. Prevalence of antibody to hantavirus in some cat populations in Britain. Vet Rec (1990) 127(22):548-9.

58. Nowotny N, Weissenboeck H, Aberle S, Hinterdorfer F. Hantavirus infection in the domestic cat. JAMA (1994) 272(14):1100-1. doi:10.1001/jama.1994. 03520140030020

59. Nowotny N. The domestic cat: a possible transmitter of viruses from rodents to man. Lancet (1994) 343(8902):921. doi:10.1016/S0140-6736(94) 90043-4

60. Zhao-Zhaung L, Hao H, Yue-Xian L. Characteristics of EHF virus isolated from cats in endemic area of Anhui province. Zhonghua Min Guo Wei Sheng Wu Ji Mian Yi Xue Za Zhi (1985) 5:81-3.

61. Xu Z, Tang Y, Kan L, Tsai T. Cats - source of protection or infection? A casecontrol study of hemorrhagic fever with renal syndrome. Am J Epidemiol (1987) 126:942-8.

62. Eis-Hubinger AM, Gerritzen A, Schneweis KE, Pfeiff B, Pullmann H, Mayr A, et al. Fatal cowpox-like virus infection transmitted by cat. Lancet (1990) 336(8719):880. doi:10.1016/0140-6736(90)92387-W

63. Baxby D, Bennett M. Low risk from feline cowpox. Lancet (1990) 336(8722):1070-1. doi:10.1016/0140-6736(90)92543-Q

64. What's new pussycat? Cowpox. Lancet (1986) 2(8508):668.

65. Willemse A, Egberink HF. Transmission of cowpox virus infection from domestic cat to man. Lancet (1985) 1(8444):1515. doi:10.1016/S0140-6736(85) 92299-8
66. Pether JV, Trevains PH, Harrison SR, Baxby D, Bennett M, Gibb AP. Cowpox from cat to man. Lancet (1986) 1(8471):38-9. doi:10.1016/S0140-6736(86) 91916-1

67. Bennett M, Gaskell CJ, Gaskell RM, Baxby D, Gruffydd-Jones TJ. Poxvirus infection in the domestic cat: some clinical and epidemiological observations. Vet Rec (1986) 118(14):387-90. doi:10.1136/vr.118.14.387

68. Chitty D, Phipps E. Seasonal changes in survival in mixed populations of two species of vole. J Anim Ecol (1966) 35:313-31. doi:10.2307/2398

69. Gibson D, Delany MJ. The population ecology of small rodents in Pennine woodlands. J Zool (1984) 203:63-85. doi:10.1111/j.1469-7998.1984. tb06044.x

70. Kim GR, Lee YT, Park CH. A new natural reservoir of Hantavirus: isolation of Hantaviruses from lung tissues of bats. Arch Virol (1994) 134(1-2):85-95. doi:10.1007/BF01379109

71. Philbey AW, Kirkland PD, Ross AD, Davis RJ, Gleeson AB, Love RJ, et al. An apparently new virus (family Paramyxoviridae) infectious for pigs, humans, and fruit bats. Emerg Infect Dis (1998) 4(2):269-71. doi:10.3201/eid0402. 980214

72. Young PL, Halpin K, Selleck PW, Field H, Gravel JL, Kelly MA, et al. Serologic evidence for the presence in Pteropus bats of a paramyxovirus related to equine morbillivirus. Emerg Infect Dis (1996) 2(3):239-40. doi:10.3201/ eid0203.960315

73. Young P. Possible reservoir host of equine morbillivirus identified. Commun Dis Intell (1996) 20:262.

74. Luis AD, Hayman DT, O'Shea TJ, Cryan PM, Gilbert AT, Pulliam JR, et al. A comparison of bats and rodents as reservoirs of zoonotic viruses: are bats special? Proc Biol Sci (2013) 280(1756):20122753. doi:10.1098/rspb.2012. 2753

75. Komar N. West Nile virus: epidemiology and ecology in North America. Adv Virus Res (2003) 61:185-234. doi:10.1016/S0065-3527(03)61005-5

76. Petersen LR, Marfin AA, Gubler DJ. West Nile virus. JAMA (2003) 290(4):524-8. doi:10.1001/jama.290.4.524

77. Campbell GL, Marfin AA, Lanciotti RS, Gubler DJ. West Nile virus. Lancet Infect Dis (2002) 2(9):519-29. doi:10.1016/S1473-3099(02)00368-7

78. Olsen C. Zoonotic Disease Tutorial. Department of Pathological Sciences, School of Veterinary Medicine, University of Wisconsin-Madison (2004). Available from: http://www.vetmed.wisc.edu/pbs/zoonoses/

79. Webster RG, Shortridge KF, Kawaoka Y. Influenza: interspecies transmission and emergence of new pandemics. FEMS Immunol Med Microbiol (1997) 18(4):275-9. doi:10.1111/j.1574-695X.1997.tb01056.x

80. Hoss HE, Olson C. Infectivity of bovine C- type (leukemia) virus for sheep and goats. Am J Vet Res (1974) 35(5):633-7.

81. McClure HM, Keeling ME, Custer RP, Marshak RR, Abt DA, Ferrer JF. Erythroleukemia in two infant chimpanzees fed milk from cows naturally infected with the bovine C-type virus. Cancer Res (1974) 34(10):2745-57.

82. Van Der Maaten MJ, Miller JM. Induction of lymphoid tumors in sheep with cell-free preparations of bovine leukemia virus. Bibl Haematol (1975) 43:377-9.

83. Beare AS, Webster RG. Replication of avian influenza viruses in humans. Arch Virol (1991) 119(1-2):37-42. doi:10.1007/BF01314321

84. Morgan HR. Antibodies for Rous sarcoma virus (Bryan) in fowl, animal, and human populations of East Africa. II. Antibodies in domestic chickens, wildfowl, primates, and man in Kenya, and antibodies for Burkitt lymphoma cells in man. J Natl Cancer Inst (1967) 39(6):1229-34.

85. Kida H, Ito T, Yasuda J, Shimizu Y, Itakura C, Shortridge KF, et al. Potential for transmission of avian influenza viruses to pigs. J Gen Virol (1994) 75(Pt 9):2183-8. doi:10.1099/0022-1317-75-9-2183

86. Scholtissek C, Naylor E. Fish farming and influenza pandemics. Nature (1988) 331(6153):215. doi:10.1038/331215a0

87. Claas EC, Osterhaus AD, van Beek R, De Jong JC, Rimmelzwaan GF, Senne DA, et al. Human influenza A H5N1 virus related to a highly pathogenic avian influenza virus. Lancet (1998) 351(9101):472-7. doi:10.1016/S0140-6736(97) $11212-0$

88. Subbarao K, Klimov A, Katz J, Regnery H, Lim W, Hall H, et al. Characterization of an avian influenza A (H5N1) virus isolated from a child with a fatal respiratory illness. Science (1998) 279(5349):393-6. doi:10.1126/science.279. 5349.393

89. Uyeki TM, Chong YH, Katz JM, Lim W, Ho YY, Wang SS, et al. Lack of evidence for human-to-human transmission of avian influenza A (H9N2) 
viruses in Hong Kong, China 1999. Emerg Infect Dis (2002) 8(2):154-9. doi:10.3201/eid0802.010148

90. Koopmans M, Wilbrink B, Conyn M, Natrop G, van der Nat H, Vennema H, et al. Transmission of H7N7 avian influenza A virus to human beings during a large outbreak in commercial poultry farms in the Netherlands. Lancet (2004) 363(9409):587-93. doi:10.1016/S0140-6736(04)15589-X

91. Du Ry van Beest Holle M, Meijer A, Koopmans M, de Jager CM. Human-tohuman transmission of avian influenza A/H7N7, The Netherlands, 2003. Euro Surveill (2005) 10(12):264-8.

92. Shortridge KF. Pandemic influenza: a zoonosis? Semin Respir Infect (1992) 7(1):11-25.

93. Hinshaw VS, Webster RG, Easterday BC, Bean WJ Jr. Replication of avian influenza A viruses in mammals. Infect Immun (1981) 34(2):354-61.

94. Centers for Disease Control and Prevention. Recent Avian Influenza Outbreaks in Asia. Available from: www.cdc.gov/flu/avian/outbreaks/asia.htm

95. Schulman JL, Kilbourne ED. Experimental transmission of influenza virus infection in mice. Ii. Some factors affecting the incidence of transmitted infection. J Exp Med (1963) 118:267-75. doi:10.1084/jem.118.2.267

96. Roberton SI, Bell DJ, Smith GJD, Nicolls JM Chan KH, Nguyen DT, et al. Avian influenza H5N1 in viverrids: implications for wildlife health and conservation. Proc R Soc B (2006) 273(1595):1729-32. doi:10.1098/rspb.2006.3549

97. Guo YJ, Krauss S, Senne DA, Mo IP, Lo KS, Xiong XP, et al. Characterization of the pathogenicity of members of the newly established H9N2 influenza virus lineages in Asia. Virology (2000) 267(2):279-88. doi:10.1006/ viro. 1999.0115

98. Shinya K, Silvano FD, Morita T, Shimada A, Nakajima M, Ito T, et al. Encephalitis in mice inoculated intranasally with an influenza virus strain originated from a water bird. J Vet Med Sci (1998) 60(5):627-9. doi:10.1292/ jvms.60.627

99. Shinya K, Shimada A, Ito T, Otsuki K, Morita T, Tanaka H, et al. Avian influenza virus intranasally inoculated infects the central nervous system of mice through the general visceral afferent nerve. Arch Virol (2000) 145(1):187-95. doi:10.1007/s007050050016

100. Uys CJ, Becker WB. Experimental infection of chickens with influenza ATern/South Africa/1961 and Chicken/Scotland/1959 viruses. II. Pathology. J Comp Pathol (1967) 77(2):167-73. doi:10.1016/0021-9975(67)90007-2

101. Takahashi M, Yamada T, Nakajima S, Nakajima K, Yamamoto T, Okada H. The substantia nigra is a major target for neurovirulent influenza A virus. J Exp Med (1995) 181(6):2161-9. doi:10.1084/jem.181.6.2161

102. Kawaoka Y. Equine H7N7 influenza A viruses are highly pathogenic in mice without adaptation: potential use as an animal model. J Virol (1991) 65(7):3891-4.

103. Alexander DJ. An overview of the epidemiology of avian influenza. Vaccine (2007) 25(30):5637-44. doi:10.1016/j.vaccine.2006.10.051

104. Prosser D, Hungerford L, Erwin R, Ottinger M, Takekawa J, Ellis E. Mapping avian influenza transmission risk at the interface of domestic poultry and wild birds. Front Public Health (2013) 1:28. doi:10.3389/fpubh.2013.00028

105. Efird JT, Holly EA, Preston-Martin S, Mueller BA, Lubin F, Filippini G, et al. Farm-related exposures and childhood brain tumours in seven countries: results from the SEARCH International Brain Tumour Study. Paediatr Perinat Epidemiol (2003) 17(2):201-11. doi:10.1046/j.1365-3016.2003. 00484.x

106. Bunin GR, Buckley JD, Boesel CP, Rorke LB, Meadows AT. Risk factors for astrocytic glioma and primitive neuroectodermal tumor of the brain in young children: a report from the Children's Cancer Group. Cancer Epidemiol Biomarkers Prev (1994) 3(3):197-204.

107. Menegoz F, Little J, Colonna M, Arslan A, Preston-Martin S, Schlehofer B, et al. Contacts with animals and humans as risk factors for adult brain tumours. An international case-control study. Eur J Cancer (2002) 38(5):696-704. doi:10.1016/S0959-8049(01)00423-3

108. Ruder AM, Carreon T, Butler MA, Calvert GM, Davis-King KE, Waters MA, et al. Exposure to farm crops, livestock, and farm tasks and risk of glioma: the Upper Midwest Health Study. Am J Epidemiol (2009) 169(12):1479-91. doi:10.1093/aje/kwp075

109. Beane Freeman LE, Deroos AJ, Koutros S, Blair A, Ward MH, Alavanja $\mathrm{M}$, et al. Poultry and livestock exposure and cancer risk among farmers in the agricultural health study. Cancer Causes Control (2012) 23(5):663-70. doi:10.1007/s10552-012-9921-1

110. Fasal E, Jackson EW, Klauber MR. Mortality in California veterinarians. J Chronic Dis (1966) 19(3):293-306. doi:10.1016/0021-9681(66)90133-0

111. Kinlen LJ. Mortality among British veterinary surgeons. Br Med J (Clin Res Ed) (1983) 287(6398):1017-9. doi:10.1136/bmj.287.6398.1017

112. Fear NT, Roman E, Ansell P, Bull D. Malignant neoplasms of the brain during childhood: the role of prenatal and neonatal factors (United Kingdom). Cancer Causes Control (2001) 12(5):443-9. doi:10.1023/A:1011201524589

113. Linet MS, Gridley G, Cnattingius S, Nicholson HS, Martinsson U, Glimelius B, et al. Maternal and perinatal risk factors for childhood brain tumors (Sweden). Cancer Causes Control (1996) 7(4):437-48. doi:10.1007/BF00052670

114. McKinney PA, Juszczak E, Findlay E, Smith K, Thomson CS. Pre- and perinatal risk factors for childhood leukaemia and other malignancies: a Scottish case control study. Br J Cancer (1999) 80(11):1844-51. doi:10.1038/sj.bjc.6690609

115. Thomas F, Lafferty KD, Brodeur J, Elguero E, Gauthier-Clerc M, Misse D. Incidence of adult brain cancers is higher in countries where the protozoan parasite Toxoplasma gondii is common. Biol Lett (2012) 8(1):101-3. doi:10.1098/rsbl.2011.0588

116. Greenland S, Morgenstern H. Ecological bias, confounding, and effect modification. Int J Epidemiol (1989) 18(1):269-74. doi:10.1093/ije/18.1.269

117. Blair A, Malker H, Cantor KP, Burmeister L, Wiklund K. Cancer among farmers. A review. Scand J Work Environ Health (1985) 11(6):397-407. doi:10.5271/sjweh.2208

Conflict of Interest Statement: The authors declare that the research was conducted in the absence of any commercial or financial relationships that could be construed as a potential conflict of interest.

Received: 11 September 2013; accepted: 31 January 2014; published online: 13 February 2014.

Citation: Efird JT, Davies SW, O'Neal WT and Anderson EJ (2014) Animal viruses, bacteria, and cancer: a brief commentary. Front. Public Health 2:14. doi: 10.3389/fpubh.2014.00014

This article was submitted to Epidemiology, a section of the journal Frontiers in Public Health.

Copyright (C) 2014 Efird, Davies, O'Neal and Anderson. This is an open-access article distributed under the terms of the Creative Commons Attribution License (CC BY). The use, distribution or reproduction in other forums is permitted, provided the original author(s) or licensor are credited and that the original publication in this journal is cited, in accordance with accepted academic practice. No use, distribution or reproduction is permitted which does not comply with these terms. 